\title{
LEXICON
}

\begin{tabular}{lll}
\hline VOLUME 2 & Number 2, October 2013 & Page 160 - 169 \\
\hline
\end{tabular}

\section{THE USE OF PRONOUN IN THE JAKARTA POST AND JAKARTA GLOBE}

\author{
Miftakhur Rofi'ah
}

\section{INTISARI}

Penelitian ini mengidentifikasi penggunaan pronomina di The Jakarta Post dan Jakarta Globe. Secara khusus, penelitian ini bertujuan untuk mengetahui frekuensi pronomina dan strategi dalam menggunakan pronomina. Data yang digunakan dalam penelitian ini diambil dari 30 artikel di dua surat kabar. Penelitian ini menggunakan teori pronomina di A Grammar of Contemporary English oleh Quirk, dkk. (207 - 228) yang membagi pronomina menjadi lima subkelas; pronomina pusat, pronomina relatif, pronomina interogatif, pronomina demonstratif, dan pronomina tidak tentu. Dalam setiap surat kabar, jumlah pronomina dihitung dan dibandingkan. Strategi dalam menggunakan pronomina pada kedua surat kabar juga dianalisis. Hasil dari penelitian ini menunjukkan bahwa frekuensi pronomina di The Jakarta Post lebih sedikit dari pada di Jakarta Globe. Kedua surat kabar tersebut memiliki lima strategi yang sama dalam menggunakan pronomina. Selain itu, The Jakarta Post mempunyai tiga strategi pronomina yang berbeda, dan Jakarta Globe mempunyai dua lainnya. Hasil- hasil ini menunjukkan bahwa kedua surat kabar tersebut memiliki persamaan dan perbedaan dalam menggunakan pronomina.

Kata kunci: pronomina, surat kabar, frekuensi pronomina, strategi dalam menggunakan pronomina.

\begin{abstract}
This research identified the use of pronoun in The Jakarta Post and Jakarta Globe. In particular, it aimed to investigate the frequency of pronoun and the strategy in using pronoun. The data used in this research were taken from 30 articles in the two newspapers. It used the pronoun theory in A Grammar of Contemporary English by Quirk, et al. (1985: 207-228) which divide pronoun into five subclasses; central pronoun, relative pronoun, interrogative pronoun, demonstrative pronoun, and indefinite pronoun. Within each newspaper, the number of pronoun will be counted and compared. The strategy in using pronoun in both newspapers was also analyzed. The results of this research show that the frequency of pronoun in The Jakarta Post is less than in Jakarta Globe. Both newspapers have five similar strategies in using pronoun. Besides that, The Jakarta Post has three more different strategies, and Jakarta Globe has two more. These results conclude that each newspaper has similarity and dissimilarity in using pronoun.
\end{abstract}

Keywords: pronoun, newspaper, frequency of pronoun, strategy in using pronoun. 


\section{INTRODUCTION}

English has dominated the exchange of news around the world, in different types of media. The Jakarta Post and Jakarta Globe are daily newspapers in English published in Indonesia. They spread the news using English which is not the mother tongue of Indonesians. Furthermore, their news is sometimes written by Indonesians. It is interesting because in news writing, the writers should not only be able to arrange the words and retell story but also be able to select some keys words. They also should have a good grammar to avoid the errors or mistakes in news writing. The use of pronoun in journalistic writing may produce the vague sentence. It becomes important because pronoun can build the cohesion in text. It helps the sentence to build up a text and make sure a text have a clear connectedness. A pronoun is word that substitute for nouns or noun phrases and designates people or things asked for, previously specified, or understood from the context. It refers to a noun or noun phrase that has been previously mentioned in speaking or writing. The reference noun that is replaced by pronoun is called the antecedent (Gerber 375). The pronouns in English consist of I, you, he, she, they, we, me, her, him, them, us, who, which, whom, whose, that, those, this, these, all, several, many, any- series, some- series, and noseries. For example, in the following sentence, the pronoun she is a pronoun that refers to the noun Jenny (name): Jenny shows off the bronze medal she won at the chess competition.

This research attempts to analyze the use of pronoun in The Jakarta Post and Jakarta Globe especially the frequency and strategy in using pronoun. The data source of this research is the article in The Jakarta Post and Jakarta Globe which was published in 2, 9, 17, 23, and 30 October 2013. Content analysis was used in the data analysis, because this method is appropriate in research which uses newspapers as the data source. The data were analyzed based on the subclasses of pronoun in A Grammar of Contemporary English by Quirk et al. (207-228).

\section{PRONOUN}

Pronouns are words which can replace an earlier noun or noun phrase (Leech \& Svartvik 275). Pronouns can be used instead of noun to avoid repetition of nouns. Without pronouns, a sentence may become really long and awkward because of repeating some nouns that are already mentioned. Based on Quirk et al. (207) in $A$ Grammar of Contemporary English, there are five subclasses of pronoun; central pronouns, relative pronouns, interrogative pronouns, demonstrative pronouns, and indefinite pronouns.

\section{a. Central Pronouns}

Central pronouns are divided into personal pronouns, possessive pronouns, and reflexive pronouns. Personal pronouns can indicate the gender (masculine, feminine, or neutral) and the case (subject or object) (Leech and Svartvik 259). For example,

[1] She is beautiful. (She is the subject of the sentence)

Possessive pronouns show the possession of something. They also depend with gender (his and hers) and the person $\left(1^{\text {st }}\right.$ person mine and ours, $2^{\text {nd }}$ person yours, and $3^{\text {rd }}$ person his, hers and theirs) (Thompson Martinet 75). For example,

Betty found her dress but Mary couldn't find hers. (Hers shows the possession of dress by Mary)

Reflexive pronouns are pronouns that are used to indicate that the subjects act upon themselves. They end with -self or selves; myself, yourself, himself, herself, itself, ourselves, and themselves. (Quirk et al., 211). For example, 
[3] Brandon blames himself for the accident. (Himself refers back to Brandon)

\section{b. Relative Pronouns}

Relative pronouns are pronouns that relate a relative clause to the rest of the sentence. The choice of relative pronouns is determined by the way the pronouns are used and the noun or pronoun to which they refer. Here is a table of relative pronoun (Quirk et al. 215).

\begin{tabular}{|c|c|c|}
\hline & Personal & $\begin{array}{c}\text { Non- } \\
\text { Personal }\end{array}$ \\
\hline \multirow{2}{*}{ Subjective case } & Who & Which \\
\hline & That & That \\
\hline \multirow{3}{*}{ Objective case } & Whom & Which \\
\hline & That & That \\
\hline & (Zero) & (Zero) \\
\hline Genitive case & Whose & \\
\hline
\end{tabular}

For example,

[4] Katie, who is my neighbor, is Brandon's girlfriend. (Who refers to Katie (a person))

\section{c. Interrogative Pronouns}

Interrogative pronouns are pronouns that are used to introduce a question. They are who, whom, whose, what, and which. They are formally identical with the relative pronoun, but they are functionally different (Quirk, et al. 216). Moreover, there are two kinds of question; direct and indirect. Direct question is followed by question marks, and indirect question is not. However, they still express the intention of questioning something. For example,

[5] Who are you? -- Direct Interrogative. (Asking to and about person)

[6] I am curious which books you like. - Indirect Interrogative. (Asking about the choice of books)

\section{d. Demonstrative Pronouns}

Demonstrative pronouns are words that are used to point out something (Jesperson 156). The most common demonstrative pronouns are this (plural these) which refer to what is near at hand, and that (plural those) which generally refers to what is farther away. For example,

[7] This is well-written. (This is used to point out the singular noun that is near)

[8] Those are very serious. (Those is used to point out the plural noun that is far)

\section{e. Indefinite Pronouns}

Indefinite pronouns are words which stand for an indefinite number or quantity of persons or things (Frank 23). They do not substitute for specific noun but function itself like noun. For example,

[9] Everyone is wondering why she left.

Everyone in example [9] replaces to unspecified person and acts as a noun in sentence.

\section{AGREEMENT IN USING PRONOUN}

Every pronoun must agree with noun or noun phrase that becomes its antecedent. The agreement covers when the pronouns match in gender, person, and number (Thompson N. 455).

\section{a. Gender}

Pronouns must have the same kind of gender with the noun or noun phrase it refers to; whether it is masculine (he, his, and him), feminine (she, her, and her) or neutral (it, its, they, them, their, theirs) (Benner). Example:

[10] The victim's father, also a public minivan driver, said that he had often warned his daughter about befriending strangers online. 
Example [10] shows the agreement between antecedent and the pronoun. Father is always masculine, so in example [10], it uses he and his as its pronoun.

\section{b. Person}

Pronouns must have exactly same person with the noun or noun phrase it refers to; whether it is the first person (the person who is speaking), the second person (the person to whom the speaker speaks), and the third person (the person who is spoken about). Moreover, although the antecedent and the pronoun agree in number, they sometimes do not agree in gender. Example:

[11] Every person in Indonesia has the right to profess his or her own religion.

Every person is singular third person pronoun which has unidentified gender. It can be replaced by pronoun he or she.

\section{c. Number}

Pronouns have to match in number with the noun or noun phrase they refer to; whether they are singular or plural. Example:

\section{[12a] Some Lenteng Agung residents,} however, have expressed confidence in his ward chief. (Incorrect) [12b] Some Lenteng Agung residents, however, have expressed confidence in their ward chief. (Correct)

It is important to note that if the noun or noun phrase is plural, it must use a plural pronoun. On example, the noun phrase some Lenteng Agung residents shows that it is plural with determine some and suffix $-s$.

\section{THE FREQUENCY AND STRATEGY OF} PRONOUN IN THE JAKARTA POST AND JAKARTA GLOBE

\section{The Frequency of Pronoun in The} Jakarta Post and Jakarta Globe

The result shows that Jakarta Globe uses more pronouns than The Jakarta Post. There were 258 pronouns found in The Jakarta Post and 299 in Jakarta Globe. In every article, The Jakarta Post and Jakarta Globe have different number of pronoun occurrence depending on the way the journalist writes the news. According to McKane (105), the best news stories tell the readers as much as possible as briefly as possible. They also do so in language that is easily understood. It means that the choice of words to describe the news will be short and clear sentence so the readers do not have trouble to understand. Relating with pronoun, it has some consideration in using pronoun in news writing. For example the use of pronoun $I$, we, and you should be in direct sentence to avoid personal language in the news writing (McKane 119).

Table 1 shows the frequency and distribution of pronoun into its subclasses on each newspaper. 
Table 1. The Frequency and Distribution of pronoun in The Jakarta Post (JP) and Jakarta Globe (JG)

\begin{tabular}{cccccccc}
\hline \multirow{2}{*}{ No. } & Types of & \multicolumn{2}{c}{ JP } & \multicolumn{2}{c}{ JG } & \multicolumn{2}{c}{ Total } \\
\cline { 2 - 7 } & Pronoun & No. & $\mathbf{\%}$ & No. & $\%$ & No. & $\%$ \\
\hline $\begin{array}{l}\text { Central } \\
\text { Pronoun }\end{array}$ & 183 & 32.9 & 207 & 37.2 & 390 & 70.0 \\
\hline 2. & $\begin{array}{l}\text { Relative } \\
\text { Pronoun }\end{array}$ & 55 & 9.9 & 66 & 11.8 & 121 & 21.7 \\
\hline 3. $\begin{array}{l}\text { Interrogative } \\
\text { pronoun }\end{array}$ & 7 & 1.3 & 7 & 1.3 & 14 & 2.5 \\
\hline 4. $\begin{array}{l}\text { Demonstrative } \\
\text { pronoun }\end{array}$ & 8 & 1.4 & 9 & 1.6 & 17 & 3.1 \\
\hline 5. $\begin{array}{l}\text { Indefinite } \\
\text { Pronoun }\end{array}$ & 5 & 0.9 & 10 & 1.8 & 15 & 2.7 \\
\hline & Total & $\mathbf{2 5 8}$ & $\mathbf{4 6 . 3}$ & $\mathbf{2 9 9}$ & $\mathbf{5 3 . 7}$ & $\mathbf{5 5 7}$ & $\mathbf{1 0 0 . 0}$ \\
\hline
\end{tabular}

There are 258 pronouns in The Jakarta Post and they have all subclasses of pronoun. There are 183 central pronouns, 55 relative pronouns, seven interrogative pronoun, eight demonstrative pronouns, and five indefinite pronouns.

The total number of pronouns in Jakarta Globe is 299 data. The highest number of pronoun subclasses occurrence is on central pronoun with 207. In other hand, there are 66 relative pronouns, seven interrogative pronouns, nine demonstrative pronouns, and 10 indefinite pronouns which are found.

Both newspapers have the highest number of pronoun subclasses in the same subclasses, central pronoun. It means that from the 557 occurrences of pronoun in The Jakarta Post and Jakarta Globe, central pronoun has the highest percentage, $70.1 \%$. Central pronoun consists of personal, possessive, and reflexive pronoun. Central pronoun has a reference for masculine, feminine, and neutral, whether as subject or object, and possessive (Benner) which is commonly used in writing. Moreover, central pronoun shows the plurality and singularity in thing or person. The central pronoun is the most frequent pronoun in both newspapers which indicates that it has an important role in building the cohesion in the text. Abbot argues in "In Praise of Personal Pronouns", that by using several personal pronouns in the writing, it is more lively and more likely to be understood. The use of pronoun allows readers and listeners to build a personal connection. Moreover, the second-person pronoun (you, yourself, yours) which should be avoided in journalistic writing (McKane 119), also appear in the data. There are six pronouns you in 390 occurrences the central pronoun. The other pronoun which should be avoided in journalistic writing is the first person pronoun ( $I$, me, myself, mine). McKane (119) states that people will feel that the use of pronoun $I$ implies an arrogance, so they think so with pronoun me or myself. According to Jepperson (148) the first person and second person of pronoun may lead to individual motives. So, it is avoided in journalistic writing because news stories should be an objective, dispassionate account of events, not something in which the writer injects his or her opinions. However, The Jakarta Post and Jakarta Globe still use them in some consideration which will be discussed more in strategy on pronoun in each newspaper in next part of this chapter.

The second place of the highest pronoun occurrence is relative pronoun, $21.7 \%$. Relative clauses are useful because they enable writers to be more specific and make their writing more sophisticated (Hunter College Reading/Writing Center ). Furthemore, relative pronoun also introduces dependent clauses that modify nouns or another pronoun- to make clear and give additional information in person or thing talking about. It makes relative pronoun frequently used in writing, including in journalistic writing. However, the considerations in journalistic writing-should always be as brief and concise as possible-- make the writer sometimes omits the relative pronoun. For example,

[13a] I disagreed with most of the points that she raised. 
[13b] I disagreed with most of the points $\varnothing$ she raised.

Sentence [13a] and [13b] has the same meaning although the relative pronoun that on the [13b] is omitted. It is not the only reason why the use of relative pronoun in newspaper article is less than central pronoun. The other reason is the function of relative pronoun itself that is not always important in writing text.

Interrogative pronoun has the lowest frequency from data analysis, $2.5 \%$. It is not surprised because interrogative case in journalistic text is used by the journalist to gain information for writing the article. From the two kinds of interrogative forms (direct and indirect), indirect has higher frequency used than the direct in the data analysis. It because in writing a news article, there may not be a place for direct interrogative style. But sometimes, it appears in the headline or the first sentence in article to involve the readers by questioning the issue to themselves. It makes the readers will be curious with the news. McKane (57) says that the news story will answer the question in the readers' mind when they have read at the first. Unfortunately, it is not found the occurrence of interrogative pronoun as the headline of newspaper. However, direct and indirect interrogative pronoun is found in the text. There are just one direct interrogative pronoun that is found. While, indirect interrogative pronoun occurs more frequently than it. The indirect interrogative also reports a question, and it finishes with a period instead of a question mark. Different from the cental and relative pronouns which refer to a noun or noun phrase that is already mentioned., interrogative pronoun means questioning something, therefore it does not have a particular antecedent. However, every interrogative pronoun has different anwer that is pursued, e.g who is used when the sentence questions about a person.
Demonstrative pronoun is not always found in every article. It has $3.2 \%$ from 557 occurences of pronoun in The Jakarta Post and Jakarta Globe. Demonstrative pronoun (that, this, those, and these) is pointing words refer to something previously mentioned that do not need followed by a substantive. That (plural those) tends to be used as a statement for representating something which is far from the speaker. While this (plural these) is the opposite of that in use since their existence will generate a different sense. This also can be used to refer something that has a connection or near to the speaker. They should has noun clause that function as pronoun's antecedent. Moreover, when using demonstrative pronoun, people will need to indicate what they mean by pointing or otherwise gesturing toward it, or listeners will need to be looking at it as well. For this reason, demonstrative pronouns are mostly used while speaking. However, it still can be found in writing like on newspaper article with antecedent that is clearly present in the preceding sentence used demonstrative pronoun.

The occurrence of indefinite pronoun in data analysis is $2.4 \%$ from 557 occurrence of pronoun. The indefinite pronoun refers to indefinite things. It means, the writer can use it without knowing who or what it is or how many. Similar with demonstrative pronoun, indefinite pronoun is not always found in every article. It rarely used than demonstrative pronoun. The specification of indefinite pronoun which refers to unidentified person or thing sometimes makes tough for the readers understanding the writer's meaning. Indefinite pronoun can be always singular, plural, and both. Subject/verb agreement errors commonly occur as a result of the confusion when certain indefinite pronoun is used as subject, and when it is replaced by other pronoun. Considering the clarity and accuracy of news article, the use of indefinite pronoun should be careful. Among the indefinite pronouns, every- 
series and $n o-$ series are usually associated with overstatement and exaggerations and considered to be inappropriate in formal written texts (Quirk et al., 222).

\section{The Strategy in Using Pronoun in The Jakarta Post and Jakarta Globe}

As an English newspaper in non-speaking English country, The Jakarta Post and Jakarta Globe have to be careful in grammar and diction in writing news article. Relating with the use of pronoun, The Jakarta Post and Jakarta Globe have five similar strategies in using pronoun. First, they use pronoun $I$ and $W e$ with opinion verbs in direct sentence. For example,

[14] "We have not agreed on the cost of the support pillars ...," he told The Jakarta Post. (JP 84)

There are some other verbs which can show opinion e.g. believe, like, and claims, (Arnaudet and Barrett). This strategy is used to avoid personal language which is produced by pronoun $I$ and we. Second, The Jakarta Post and Jakarta Globe avoid the ambiguity of pronoun usage by using a clear antecedent. The antecedents in every pronoun must be clear to make a good cohesion in the news article and to avoid reader's confussion. From the data, they have the clear antecedents in every pronoun which replace it.

The 70-seat ATR 72-600 can take-off on runways as short as 1,333 meters. $\boldsymbol{I t}$ is also the most fuel efficient of the larger turboprops, ... (JG 19)

The example [15] shows the pronoun it refers to the previous sentence, the 70-seat ATR 72-600. Constructing sentences that contain clear relationships between the pronouns and their antecedents is important. It is because a pronoun cannot possibly refer to more than one antecedent.
Third, those two newspapers use the pronouns effectively to produce the cohesion in text. Based on Halliday and Hasan (34), there six ways to produce cohesion in text, one of them is reference. Pronoun is the most common source for reference. By using pronoun effectively, it helps to link an element of the text with the whole contents of the text. For example,

$$
\begin{aligned}
& \text {... Yuanna Sisilia, who said she } \\
& \text { used to assist Akil to make banking } \\
& \text { transactions before Akil was voted } \\
& \text { to be chief justice in April, told the } \\
& \text { panel she once wired Rp } 500 \text { million } \\
& \text { to Akil's bank account. (JP } 68,69 \text { ) }
\end{aligned}
$$

The use of pronoun she refers to Yuanna Sisilia which functions as referent in the text. So, there is no need to repeat the name of person again and again, because it can be replace by pronoun. Forth, The Jakarta Post and Jakarta Globe put relative pronoun immediately after its antecedent. This strategy aims to avoid the readers' confusion. As noted by Pérez (18) "a relative clause which does not come immediately after its antecedent is more difficult to separate from the material that intervenes if there is no relative pronoun, and on some occasions, it could produce ambiguity...." For example,

[17] Busyro refuted speculation that the lobbyist was the wife of the chief of staff of Yudhoyono's family ... (JG 245)

Relative pronoun that refers to word speculation which comes right before the relative pronoun. Last, those two newspapers use pronouns to pursue the reference agreement. It relates with agreement in using pronoun, that pronoun should agree in number, person, and gender. For example,

[18] In his testimony, Luthfi claimed that Bunda Putri was "very close" to 
Yudhoyono. In a taped conversation between him and Ridwan, which was played during Luthfi's trial,

Luthfi said that Bunda Putri

"influenced decision makers". (JP 118)

In [18] it can be seen clearly that the pronoun him refers to Lutfi. Lutfi is a male person, so it should be replaced with masculine pronoun, he, him or himself. In second sentence on example [18], Lutfi mentioned again, as possessive form and a subject, is to avoide vague pronoun because Ridwan is also male. So, it cannot be In a taped conversation between him and Ridwan, which was played during his trial,

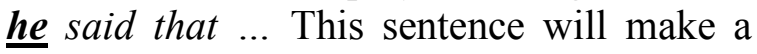
vague pronoun, which antecedent that he refers to.

Beside the similarities, The Jakarta Post and Jakarta Globe also have some differences strategy in using pronoun. The Jakarta Post has three different strategies, and Jakarta Globe has two different strategies.

The Jakarta Post uses singular pronoun to replace collective nouns. The collective nouns are nouns which stand for a group or collection of people or things. Determining it may be a problem because whether they are singular or plural depends on the context of the sentence (Quirk et al. 190). However, The Jakarta Post treats it as singular noun. For example,

[19] The BNN, however, said it would continue its investigation into Akil ... (JP49)

Second, The Jakarta Post use pronoun he/she or they to replace indefinite pronoun. It aims to avoid sex-biased when it replace the indefinite pronoun, such as anyone, everybody, somebody, etc. For example,
... the KPK has never had a tradition of giving permits to anyone to exit Indonesia if she or he has been banned ... (JP 54, 28)

Third, The Jakarta Post use direct interrogative pronoun in its article to get closer with the readers. By giving question to the readers, it will involve the readers indirectly in the issue. For example,

$$
\text { "Who was responsible for this?" }
$$

Hamdan said. (JP 240)

Jakarta Globe has two different strategies in using pronoun. First, it replaces the collective nouns with singular or plural pronouns. It aims to give information to the readers that collective nouns can act as one unit or many units (members of groups) (Rozakis 207). For example,

\section{[22] The Corruption Eradication Commission (KPK) says it knows who Bunda Putri is, ... (JG 128)}

[23] The KPK, meanwhile, said they had seized 15 cardboard boxes of documents from Chaeri's office ... (JG 40)

Second, it uses pronoun you to talk to the readers. It also can be used as strategy to get closer with the readers. However, the use of pronoun you is under consideration. It is just used in direct sentence, or between quotations. For example,

[24] "I want to set an example. If I am willing to get tested, why aren't you?" he said at City Hall after launching the campaign. (JG 78)

Those all strategies in using pronoun in The Jakarta Post and Jakarta Globe seem grammatically correct. The different of them is just the style of the newspapers in writing their articles. 


\section{CONCLUSION}

The results of this research show that the frequency of pronoun in The Jakarta Post is less than in Jakarta Globe. Based on the findings, there are 557 occurrences of pronoun in both newspapers; 258 in The Jakarta Post, and 299 in Jakarta Globe. Each subclass of pronoun has different distribution on each newspaper. First, central pronoun has the highest percentage of occurrence with $70.1 \%$ from the pronoun occurrences in both newspapers. Second, relative pronoun is the second frequently pronoun used with $21.7 \%$. Third, interrogative pronoun has $2.5 \%$. Forth, demonstrative pronoun produces $3.2 \%$ in The Jakarta Post and Jakarta Globe. Last, indefinite pronoun give distribution $2.4 \%$ in occurrence of pronoun in both newspapers.

Furthermore, there are five similar strategies in using pronoun in The Jakarta Post and Jakarta Globe. They are using pronoun $I$ and $W e$ with opinion verbs in direct sentence, using the clear antecedents to avoid the ambiguity in pronoun, using pronoun effectively to produce the cohesiveness, putting the relative pronoun generally immediately after its antecedent, and using pronoun agree in gender and number with its antecedent to pursue reference agreement. Beside that, The Jakarta Post has three different strategies. First, it use singular pronoun to replace collective nouns. Second, it avoids sex biased by using pronoun he/she or they. Last, it uses direct interrogative pronoun on the text. Furthermore, Jakarta Globe has another two different strategies in using pronoun; treating collective nouns as plural and singular and using pronoun you to involve the reader in the issue. Those strategies also show the benefits in using pronoun in newspaper.
In this research, there were only pronouns used and the focus was frequency and strategy. Further research on the same topic is suggested to support the result of this research. There is more scope of studies such as the common problem or grammatical errors in using pronoun that can be elaborated in further research.

\section{REFERENCES}

Arnaudet, M.L. \& Barrett, M.E. Approaches to Academic Reading and Writing. Englewood Cliffs, NJ: Prentice Hall Regents. 1984. Google Book Search. Web. 15 Feb 2014.

Benner, Margaret L. Pronoun. Online Writing Support: Towson University. Web. 14 Nov 2013. $<$ www.towson.edu/ows.pronoun.htm $1>$.

Frank, Marcella. Modern English: A Practical Reference Guide. New Jersey: Prentice Hall inc., 1972. Print.

Gerber, Philip L. Effective English. New York: Random House, 1959. Print.

Halliday, M. A.K. and R. Hasan. Cohesion in English. London: Longman, 1976. Print.

Jesperson, Otto. Essential of English Grammar.London: George Allen\& Unwin Ltd., 1952. Print.

Leech, Geoffrey and Jan Svartvik. $A$ Communicative Grammar of English. London: Longman, 1981. Print.

McKane, Anna. News Writing. London: Sage Publication, 2006. Pdf file. 
Perez, Diaz and Francisco Javier. "Relative Connectives in Present-Day English: A corpus-Based Analysis." Miscelanea: A Journal of English and American Studies. 1997: 18. Pdf file.

Quirk, Randolph, Sidney Greenbaum, Geoffrey Leech, and Jan Svartvik. A University Grammar of English. London: Longman Group, 1973. Print.
Rozakis, Laurie E. The Complete Idiot's Guide to Grammar and Style, 2nd Edition. New York: Marie ButlerKnight, 2003. Pdf file.

Thompson, N. Wayne. Fundamentals of Communication: A Manual Written Usage. New York: Mc Graw-Hill Book Company Inc., 1957. Print. 